\title{
Historical Investigation to the Problems and Challenges of Muslims in Papua New Guinea
}

\author{
Ibraheem Mikail Abiola, Haruna Umar Farouq, and Maruf RajiOwoyemi
}

\begin{abstract}
It is not difficult to see why Muslims who live as a minority innon-Muslimcountries like Papua New Guinea are seen as a problem and threat.These are partly due to political and historical factors, partly due to the press media, which have unjustly confirmed for many that Muslims are violent, prone to anarchy. Mostnon-Muslimcountries like Papua New Guinea in which Muslims live have an image of themselves as plural, secular, modern and tolerant societies. Muslims somehow challenge such an image; they provoke the worst aspect of the state hence, instead of solving the problems of the Muslims in a manner that would be mutually beneficial, the state tends to ignore or minimize them. The examples of Papua New Guinean minority Muslims are like that of former state of Yugoslavia where the Serbs went one step further with Muslim minority. They systematically terrorized them and sent them from their homes, the world called it ethnic cleansing and did nothing.Bosnia was added to the list of recent Muslim losses. Can the same fate happen in Papua New Guinea? What offends Muslims living in a country as the minority community?
\end{abstract}

Index Terms-Papua new guinea, muslims, community, historical.

\section{INTRODUCTION}

Papua New Guinea occupies the eastern half of the island of New Guinea, just north of Australia, and many outlying islands. The Indonesian province of West Papua (Irian Jaya) is to the west. To the north and east are the islands of Manus, New Britain, New Ireland, and Bougainville, all forming a part of Papua New Guinea. [1] Aboutone-tenthlarger than California, its mountainous interior has only recently been explored. Two major rivers, the Sepik and the Fly, are navigable byshallow-draftvessels. The population of Papua New Guinea was 3.1 million in 1983 and increased to 5 million in 1999.At present, the total population of Papua New Guinea is 6 million with Muslims estimated as only $1 \%$ of the population. Comprising many different tribal and ethnic groups, the population is increasing at an estimated rate of $2.4 \%$ per annum. [2]

Although English is the official major language and is widely taught and spoken, the country has so many different dialects many of which are common use. After English, Pidgin English and Motu are the main lingua franca. [3]

\section{FULL PAPER}

Manuscript received March18, 2015; revised July 20, 2015. 2015.

The authors are with the Department of History and Civilization, International Islamic University Malaysia (IIUM), Malaysia (e-mail: ibraheem_abiola@yahoo.com).
There are some aspects that Muslims of Papua New Guinea are sensitive of and having challenges and problems in, these are:

\section{A. Religious Freedom}

Despite the constitutional promise of religious freedom, it is still denied in Papua New Guinea and persecution is pervasive, religion is not only denied but more prevalent in most Christian dominant countries. One irony of Christian minority countries, many of whom defend legal restrictions under the premises of protecting the religion, is that the harshest religious prosecution is often directed at other Christians, such as Catholics in Africa and in some parts of Europe. Governments in more than seven out of 10 majority Christian countries harass Muslims, while Christians are harassed in only three to 10 Muslim majority countries [4]. In some cases there is a direct physical attack to Muslims and the mosque in Port Moresby is vandalized. There is more sinister danger of actual history being changed and Muslim culture being depicted in National dailies in Papua New Guinea as barbaric and worthless [5].

Muslims of Papua New Guinea would like to be able to visit their mosque in Port Moresby and say their prayers peacefully without interruption, without being beaten up, without being harassed. They would also like privacy in their homes where they can lead their lives as a Muslim in particularly, for the elderly, the women and the children. They don't like police or paramilitary forces bursting into their homes and humiliating their families. [6] These are agonizing dilemmas facing Muslims as a minority in Papua New Guinea, in a different time, Muslims persecuted by the majority could do one of two things especially the expatriates among the Muslims: They could pack up and leave, that is, exercise the right to adopt Hijra, or they could fight for their rights (jihad) that is the for the citizen of the country. Minorities have always been part of many Muslims across the whole world and on the whole they have been left alone, indeed often participating in the state by holding the highest position. [7] The problem is therefore not only minority Muslims but majority non-Muslims, if the majority is a little bit more tolerant and imaginative it will be able to deal with the minorities more fairly and more kindly, and Muslims in return would respond more positively. [8] Power is both corrupting and dangerous when it is unchallenged and concentrated in the hands of the majority as it is in Fiji Island and Papua New Guinea; the nonMuslim voices of tolerance and compassion are easily drowned. Poverty has been a major challenge of Muslims who are concentrated in the capital city Port Moresby and Lae province. It is estimated that the average human poverty index of Muslims is above 75percent. "Inhabitants from these areas have had difficulties in payment of schools' fees 
and access to adequate education, they mostly pastoralists, thus having nothing to sell to offset fees arrears" said one of the Islamic Society members. Muslims in some remote areas of Papua New Guinea face problems of land ownership as the Christian missionaries had been denying them title to their land for a long time [9].

\section{MuSLIM IDENTITY AND SOCIAL PROBLEMS}

The challenges and problems facing Muslims in Papua New Guinea requires an understanding of the shift in ideology, social, religious and political forces that are shaping the structure and functions of Muslims in Papua New Guinea. Muslim families in Papua New Guinea are static or monolithic, each family is unique, yet it is a microcosm of the society at large and is reflective of religious, social and political values. The challenges facing Muslims in Papua New Guinea is to not only maintain its Islamic identity, but to initiate changes in the social and political spheres in the light of the principle of the noble Qur'an [10].

To achieve these goals Muslims are required to actively participate in the politics, social, economic, and religious aspects of the society. Failing this, Muslims in Papua New Guinea will either be segregated or assimilated; the processes are undesirable since this will lead to the loss of self identity, which is built on religious and social values acquired from one's Muslim family and strengthened through constant interaction with the entire country.Over the past years, the Papua New Guineans have experienced rapid social, political and religious changes and transformation, resulting in high divorce rate, separation, single parent families and common law relationships. There are childless couples and increasing numbers of women choosing to work outside the house. However data collected from different sources including the writer of Problems facing Islam in Papua New Guinea and the Pacific and request for support....Indicate thatover the past years the Muslims in Papua New Guinea are experiencing social, political and ideological problems which are in terms of their social functionality reflected on the psychological and emotional aspects [11].

In addition, a significant number of young Muslims are not marrying at the right time due, major hurdles for young Muslims to find someone to marry from within the diverse Muslim society involves is the question of ethnicity and culture. Cultural and racial diversity instead of being a positive factor is becoming a dividing factor among the Muslims in Papua New Guinea, since every identity wants to preserve its own ethnic group and cultural purity. The social trends within the Muslim community points to various degree of assimilation, or adaptation to existing societal values.Imam Mikail Abdul Aziz thus said:

The first and foremost factor is very strict tribal ties and their culture. It is now over thirty years that Islam has been established there but they still do not marry in a different tribe. I told them repeatedly and I hope still they are being advised but it is quite hard for them to go against the traditions of their tribe. There are cases where a family with young marriageable age has accepted Islam and there is no Muslim youth in their tribe, they are facing difficulties in

\section{finding a match [12].}

This is a serious implication for the future of Islam and Muslims of Papua New Guinea. Muslims are required by their faith to create a stable environment and enhance life and civilization; meanwhile if Muslims fail to maintain a sound religious society and social values for the physical and psychological growth of Papua New Guinea, then Muslims will suffer greatly in future and they will not be able to match and keep pace with Christianity influence and its impact in Papua New Guinea [13].

\section{ISLAMIC EDUCATION}

Islamic institutions and schools are not easy to establish in Papua New Guinea due to constitutional restriction by the government and its policy of curtailing the establishment of Islamic schools, which is crucial to a thriving Muslim community. Yet, despite this fact the Islamic Society of Papua New Guinea provides some sort of basic Quran lessons inside the mosque where Muslim children can learn how to read the Holy Quran. The nature of life in a non Muslim country like Papua New Guinea is such that most Muslims are still unable to meet some fundamental obligations like providing Islamic education for their children [9]. The odd working hours, great distance, and the scarcity of Quran tutors in Papua New Guinea, all combine to make the arrangements for Islamic learning and Quran class a daunting task for Muslims of Papua New Guinea. Muslims have the lowest literacy rate and Islamic education of Muslims in Papua New Guinea faces many numerous challenges [8]. Parents try to teach Islamic values and morals to their children at home, because Islamic schools in Papua New Guinea are also not financially viable."There are no institutions of higher education or universities owned or managed by Muslims, in comparison to church-run universities in the country especially universities like University of Goroka, Papua New Guinea University of technology and Pacific Adventure University."Mohammad Chowdhry thus said:

There is lack of training, no proper syllabus or rigid program. It is all what your dad is doing; there is hardly anyone to assist him in true sense [14]. The primary school is quite important so that children from the very tender age are trained for Islam, however some children are being sent to Fiji but the result we have to see after a few years. It is better to have some arrangements locally. There are two students studying at Islamic University in Madinah, Saudi Arabia presently. Papua New Guineans are lazy by nature and due to the rich forest fruits and food, which they can achieve quite easily, this factor is killing them.

Fortunately, technology advancements via computers, especially voice communication over the internet, has now made it possible for Muslims in many neighbouring countries of Papua New Guinea like Australia and New Zealand to take classes online, which means Muslims parents and children can now learn how to read Quran online without having to go anywhere. Yet the Muslims of Papua New Guinea don't have access to this because of the high rate of poverty and also the slow system of government in providing and implementing a fast and efficient internet system. 


\section{HALAL FOOD}

One of the key challenges of Muslims in Papua New Guinea is the access to halal food in various grocery stores, supermarkets, and restaurants. More often than not Muslims have tried to refer back to the authorities to try and understand the nature of their need for halal food and to seek the government help in providing import of halal food processing to meet their daily consumption. Muslims have tried to suggest to the government to establish a slaughter house in accordance to Islamic rites, but this seems impractical given the government's policy of curtailing Islam especially in its dietary requirements. In many cases, Muslims are going through great difficulties in obtaining meat that is slaughtered according to the established norms of shari'ah law. [15]

In addition to the problem of obtaining halal food, Muslim travelers also face the problem of ascertaining whether the food offered to them by the airline is indeed halal. Over the years, there have been many Muslims travelers and there have been individuals who have recommended the idea of having Muslim meals onboard flights especially Air Nuigini.These Muslim meals simply mean that food served did not contain pork or alcoholic products, and finally, the airline succumbed to the idea of offering Muslim meals during the flight.

\section{LACK OF UNDERSTANDING OF ISLAM BY THE CONVERTED MUSLIMS}

Islam teaches that everyone is a Muslim by birth because every child that is born has a natural inclination to goodness and to worship the one true God alone, but his or her parent or society can cause him or her to deviate from the straight path of Islam. When someone accept Islam he or she is considered to accept the faith and revert to this original condition and origin called fitrah, this is why the term 'revert' is sometime preferred over 'convert' by Muslims as it is more consonance with Islamic belief. While conversion to Islam is supported by the tenets of the faith, it is found that the understanding of Islam by the newly converted Muslims in Papua New Guinea has become a serious concern of most senior Muslim members in Papua New Guinea. Because of difficulties in studying and reading the Qur'an and ability to live as Muslims and by Muslims traditions given the political and social realities and government constraints to compound the problem of Islamization of converts. These challenges include inheritance law, religious holidays, family law, and religious festivals, when these are considered it means Islam itself is being accepted in Papua New Guinea. This is certainly not the case. These are the challenges and difficulties Muslims are faced considering that Papua New Guinea is a new place for Islam. Mohammad Chowdhry has commented

Lack of understanding of Islam and poverty are another factor, people who are coming to Islam are usually poor and out of job and the Society do not have any funds to help them. Imam Mikail Abdul Aziz when he initially came to Papua New Guinea he used to spend almost all his wages in helping people to attract them to Islam by buying small household items for them i.e., stoves etc. We discouraged this because most people were exploiting him. [16]

It is not difficult for the non-Muslim government of Papua New Guinea to accede to the request for providing these facilities to Muslims of the country; when such facilities are given, Muslims can live harmoniously in Papua New Guinea and history confirms about the behaviour of Muslim communities worldwide who want peace and stability to practice their religion and a chance to earn a decent living. There are also cultural problems for Muslims of Papua New Guinea living as a minority. Muslim tourists are not visiting the country; Islamic cultural is directly challenged.The problem is serious because it is ongoing and does not involve only one or two countries in which Muslims live. Muslim face difficulties being in a new place for Islam, or maybe because life as a minority community can be challenging in places which includes France, Singapore, Poland, Australia, Papua New Guinea, Kenya, South Africa and so on [14].

Although the Papua New Guinea Muslims are united, leadership is still a challenge for them. In some provinces, the challenge and problems faced by Muslims is about identity, which has been disenfranchised.The area is underdeveloped and people are marginalized.

\section{CONCLUSION}

As explained in this chapter, Muslims of Papua New Guinea are facing many challenges, and it requires an understanding of the shift of ideological, social, religious, and political forces that are shaping the structure and function of families in Papua New Guinea. Muslim families in Papua New Guinea are static or monolithic,each family is unique, yet it is a microcosm of the society at large and is reflective of religious, social and political values. The challenges facing Muslims in Papua New Guinea is to not only to maintain its Islamic identity, but to initiate changes in the social and political arena according to principle contained in the noble Qur'an. There are also some other challenges such as those posed by education, the fundamental understanding of Islam, and need for halal food and other religious aspects which is impacted by unfair treatment, and government policy.

\section{REFERENCES}

[1] K. Daoud, The West and the Arab World: The Case of Media, Westerview Press, 2004, p. 87.

[2] S. Flower, The growth of Islam in Papua New Guinea: Implication for Security and Policy, PhD Diss., Australian National University, Canberra, 2010, p.132

[3] M. A. Chowdhury, My Memories of Islam in Papua New Guinea, Library of Islamic Society of Papua New Guinea, 1997, p. 22.

[4] A, Kettani, Muslim Minorities in the World Today, London: Mansell Publishing, 1986, p. 175.

[5] D. Briggs, The Price of Freedom Denied: Religious Persecution and Conflict in the Twenty-First Century, Liberty Press, 2011, p. 235.

[6] L. Kapi, Minister Misled on Islam, The National, 17 August 2000, p. 18.

[7] S. Flower, "The struggle to establish Islam in Papua New Guinea (1976-1983),"Journal of Pacific History, no.3, pp. 241-60, 2009.

[8] J. K. Wellman and K. Tokuno, "Is religious violence inevitable?" Journal for the Scientific Study of Religion, vol. 43, pp. 291-296, 2002.

[9] M. A. Chowdhry, "To international Muslims," Problems Facing Islam in Papua New Guinea and the Pacific and Request for Support, 2000, p. 14. 
[10] B. Islam, The Emergence of Islam in Papua New Guinea to the RISEAP 1998 General Assembly Meeting, Port Moresby, Islamic Society of Papua New Guinea, 1998, p. 17.

[11] J. Kapigeno, Don't Crucify other Religions and Believes for Actions of Few Churches, The National, p. 27.

[12] M. A. Chowdhry, "To international Muslims," Problems Facing Islam in Papua New Guinea and the Pacific and Request for Support, 2000, p. 15 .

[13] M. A. Chowdhry, "To international Muslims," Problems Facing Islam in Papua New Guinea and the Pacific and Request for Support, 2000, p. 19.
[14] A. Ezzati, The Spread of Islam, The Contribution Factors, London: Islamic College for Advanced Studies Press, 1997, p. 537.

[15] M. A. Chowdhry, "To international Muslims," Problems Facing Islam in Papua New Guinea and the Pacific and Request for Support, 2000, p. 22.

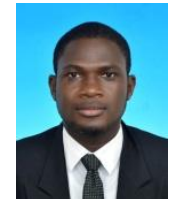

Ibraheem Mikail Abiola was born on 30 $0^{\text {th }}$ of March 1985. And he is a doctorate degree student at the Department of History and Civilization, International Islamic University Malaysia (IIUM). Previously he studied at Islamic University Madinah, Kindgom of Saudi Arabia. 